Having taken two or three grains of solid opium, and a grain of the valerianate of morphia, without relief, she begged for chloroform, which procured the desired relief. My supply was soon exhausted, and I went home to procure more. On consultation with my father, we thought best to administer to her half a grain of the sulphate of morphia, dissolved in $\mathrm{f} 3 \mathrm{i}$. of water, by subcutaneous injection, and to continue the chloroform if necessary. The solution was introduced at the inside of the middle of the right leg, near the tibia. In a few minutes she fell aslcep, and continued all night till morning-a space of eight or nine hours-in a comatose condition; pulse normal; respiration four times a minute, decp, jerking, stertorous. The effect of the imperfect oxygenation of the blood became manifest in the leaden huc of the countenance and lividity of the lips, which by morning light were so deathly that I endeavored to counteract the poisonous effect of the medicine. After pouring from the nose of a coffee-pot about two pailsful of ice-water, she opened her eyes and manifested consciousiess. But she soon relapsed into the comatose condition, only to be roused by the cold douche. She was shaken, and marched about the apartment, and about noon fully camo out of the influence of the medicine and appeared quite comfortable. About 2, A.M., of the next day she was seized with pain in the ehest, oppression of breathing and gencral prostration, which continued until death, at about noon.

At the autopsy, made the next day, the lungs were found engorged with blood, the heart filled with clots on both sides; the right kidney was evidently twice the size of the left; the right ureter was enlarged, contorted and distended; at the kidney it was ncarly three quarters of an inch in diameter, and tapered down to the normal size at the bladder. About an inch from the bladder a calculus was found impacted in the ureter. This was in two portions, both together weighing $7 \frac{1}{2}$ grains. The upper part of the kidney was invaded by an abscess of the size of a hen's egg. The pelvis of the kidney was distended with urine and pus. There was some fatty degeneration of the kidney. Elsewhere the appearances were normal.

P. S.-Fer first experience of pain was during the previous summer. The dose of the sulphate of morphia may appear large. My father, a short time before, gave two grains of the same salt by separate injections, during the course of two hours, without perceptible effect.

\title{
INDIANS OF SAN DIEGO COUNTY, CALIFORNIA.
}

By Acting Asgistant Surgeon D. B. Hopfanan, U.S.A.

Tre Indians which inhalit San Dicgo County formerly evidently belonged to one tribe. The genuine name of that tribe, when the 
whites first visited this coast, was "Los Cayotes," and they recognized Juan Antonio, at least so says their history, as their chief. He then resided in the mountains north of Warner's Rancho, at a place called by them "Cayotes." This old chicf's family still resides there, and one of his sons is the acknowledged chief of the tribe yet, bearing the same name. It is said, by the carly Spanish writcrs, that the name of this tribe comes from the fact that these Indians, when first discovered, lived mostly in caves or burrows under ground, like the animal from which they take their name; and, I am told that, in the wild mountains, they still live in the same manner. This tribe, at the time of which I write, was probably much more numcrous than at present. They scarcely number now, all told, four thousand. The Old Missions, established here during the latter part of the last century by the Catholic Missionaries, attracted many of them away from their old haunts and hunting grounds. When once initiated at a Mission, as a neoplyyte and laborer, the influence of that, to the uneducated mind, attractive religion, and the easy mode of life which they led, wholly weaned them from their forest homes. The consequence was, that the once large tribe, acknowledging allegiance to one chicf, was divided and broken up into many small tribes. Wherever there was a Pueblo or Mission, there would be found one of the small tribes located in the vicinity, in what they called the rancheria. When once settled in this manner, they appear to have renounced all allegiance to their old principal chicf, as they chose a chicf for themselves, who resided amongst them. But he, as a general thing, had little to do in their government; perhaps, now and then, they would apply to him, but oftencr they would go to the civil authority or the priest of the Mission with their complaints, and for redress of their wrongs. Thus they became a disorganized and miserable people, who were slowly allured from one step to another downwards, until quictly subdued by the meanest of motivesmercenary gain-into beasts of burden, "hewers of wood and drawers of water"; for they were made more literally slaves by the sycophantic priests who once "lorded" it over this country, than the most abject African negro that was ever heard of. Now and then, during this period, some of the more vigorous and active chiefs, ambitious to regencrate their race and retrieve it fiom the terrible thraldom into which it had been merged by superior but more brutal minds, would essay a revolt or revolution, on a small scale; but Spanish muskets and bayonets easily and quickly quelled them.

After the days of the Missions came another evil, greatly to the detriment of the poor Indian, and which well nigh exterminated them. This evil was the settlement of the country, over which they were used to roam without restraint, by the white man. With the advent of this predominant race came the precursor of the dissolution of the red children of the forest, in the shape of "firc-water," and those low, revolting diseases, known only to the low, dirty dregs of socicty- 
rakes, harlots and libertines. At the present time there are but few of them who are not either drunkards, or diseased in such a way that life is but a curse to them. Those that are still living about the towns and missions have assumed civilized habits to such an extent that there is nothing interesting or peculiar about them. Those living in their old haunts, in a still semi-sarage state, have many curious and singular customs, habits and traditional legends. Their habits of life are all very simple. They livo in villages, often numbering many wigwams or huts. These are gencrally built by driving long poles in the ground, and bending them over, so as to form an arch ; these are then thatched with straw all over, except a narrow hole in one end, which serves the purpose of a door. These villages are usually found near some stream, where there is a suffcient cxtent of good tillable land, for garden, agricultural or grazing purposes. They generally have a few head of horses, cattle and sheep, and frequently cultivate large ficlds of grain and fruit. Still they are somewhat nomadic in their habits, spending the summer in the mountains, and the winter on the coast. They also have a custom of coming down on the coast every year, at a certain time, for the purpose of taking their year's supply of fish. Instinct or experience has tanght them that, at a certain scason, millions of fish fre. quent the shore of the ocean, from some unknown cause, even to philosophers, and that, at that time, they are easily taken. Rude nets or seines, manufactured from the tenacious bark of the "tione" tree, are generally used in taking them; and they are so expert and successful that the atmosphere is rendered pestifcrous, for days at a time, in the vicinity of their fishing camps, from the refuse and surplusage, which they cannot cure before putrefaction takes place. This scason does not gencrally last more than two wecks, at the end of which time both the fish and the Indians disappear from the coast for the year. In their conjugal relations they are like "Mormons." When a brare desires a wife or wires, he, like a true Yankec, goes to the parents and bargains for them, the same as he would go to a store for tobacco or whiskey. The price is generally a horse, or the value of one in something else. Their laws allow them to keep as many wives as they can support, and also permit them to separate, or voluntarily divorce themselves, whenever either party, from any cause whatever, becomes dissatisfied with the other. This, of course, renders their morals corrupt and bad. Fidelity is unknown amongst them, and they think it no sin to "cuckold" their husbands, if they divide the spoils with him. In fact, he is so low in this respect that he will frequently hunt a bargain of this character, that he may get a drink of rum thereby.

'They have many fêtes or festivals, or, as they call them in their language, "pow-wows," during the year. These frequently end in bloody figlits, when many are killed. One of these feasts, which I have nerer yet seen a description of, and which, I believe, is not 
practised by any other known tribe, is of so extraordinary a character that I deem it worthy of description. As soon as the young fomale arrives at the age of puberty she is put, as it were, under the guard of an old woman, who closely watches her until menstruation commences. As soon as this is noticed, the tocsin is sounded for a tatumado feast. It is obligatory upon the whole tribe to attend on this occasion. As soon as they get together, they first dig a round hole in the ground, large and decp enough to take the poor girl in up to her neck. The whole tribc, except the managers, during this time, are drinking, carousing, and dancing in a circle around the scene of operations. After the hole is finished, it is filled up with dry wood, fiagrant leaves and bushes, in such a manner as to be lighted from the bottom. On the announcement that everything is ready, one of the old men of the tribe, a kind of prophet or priest, steps slowly forward toward the pile, with torch in hand, pronouncing, in a loud, clear tone, an incantation, which, for sublimity and pathos, is scarcely ever equalled by our more accomplished but less natural divines. As soon as the old man is through, a rude chant is hummed by the whole assembly. When this is closed the torch is applied, and as the flames arise heavenwards, the whole circle, on bended knee and with uplifted face, pour forth, in unison, a devout prayer for their future preservation from all evil. As soon as this ceremony is finished, the hole is filled or strewed over with fresh green fragrant leaves. The poor Indian girl is then placed, by force, in the hole, and covered up to her neck with the fresh earth just taken out. The heat left from the fire is frequently so intense as to make the poor thing writhe and howl with the most intense and burning pain for hours. No matter; the feast gocs on, and the howl of the participants drowns that of the rictim. She remains in this situation-without any food, or anything clse but water, which is given to her frequently and freely, or she would die-immovably fixed in this hot, secthing, vapor-producing hole for forty-eight hours. During all this time, dancing, singing and carousing of all kinds are kept up by the tribe around her. When she is taken out, of course she is more dead than alive, and she is taken by the old woman to a comfortable place, when she is restored and revived by the "medicine man" of the tribe. This is the signal for the breaking up of the feast, and all retire. Thus the mothers of the fair daughters of the for'cst "bring out" or notify to the world that their daughters are marriagcable. It is true that there is some difference between this method and the fashionable one now in vogue in bringing out a belle in New York; but when one reflects that the same end is obtained-a husband-by either pro. cess, it is extremcly difficult, in the abstract, to realize the difference. The women, as a general thing, marry at an early age, while the men seldom do so before their twenty-fifth year. Like Zenobia, there does not appear to be much love on cither side, and they say that 
there is no enjoyment in the whole affair, but that it is a necessity of nature for health and for the propagation of their species.

But little information can be obtained in relation to their discases. During the spring and autumn, fevers of different types prevail, to some extent, among them. I have scen them sick with the common intermittent, bilious and continued fevers. Discases of the chest, also, prevail to a considerable extent during the winter months. The exanthematous discases play sad havoc with them when they come along. Their filthy and exposed manner of living will not do for this class of discases. Of remedies they have, or at least use, but few. Each rancheria has a sweat-house. This is made by digging a large liole in the ground, and covering it over with timber, brush and earth, in the shape of a cone, making it air-tiglit, with the exception of a small hole in the top, for the escape of smole. In this hole, which they dignify with the name of "swcat-house," or casa de sudor, when anything is the matter with them, they keep a good firc, which kecps the place so warm that one who enters will, in a few moments, sweat terribly. After the patient has sweat sufficiently to satisfy their ideas of treatment, lic strips off his clothing, and rushes out as if mad, and jumps into the river, lake, or some other place filled with cold water. As soon as this becomes insupportable, he jumps out and runs or jumps about, until reaction takes placc. $\Lambda$ fter this terrible ordeal, he drinks herb tea, \&c., and if he is not cured, repeats the same dose cvery day, until he gets well or dies. This is the treatment for most of their discases. Isast winter one of them had the smallpox: he tried this remedy. It did very well until he got into the cold water, where he died before he could get out. I have scen them conc out of one of these swcat-houses, seething and sweating at crery pore, in the winter time, when there was snow on the ground and ice along the margin of the river-and plunge into the cold water, as if it were nothing. How they can stand the sudden shock, I am unable to discorer; but they do it with as much nonchalance as a Fienchman affects a duel.

For gonorrhoea they use a strong decoction of an herb that grows very plentifully herc, and is called by the Spanish "chancel agua," and wild-pigcon manure, rolled up into pills. The decoction is a very bitter astringent, and may curce some sores; but that it fails in many, I have undeniable proof. In syphilis they use the actual cautery - a living coal of fire applied to the chancre-and a decoction of an herb, said to be something like sarsaparilla, called rosia. It does not grow in this vicinity, and as I have never been able to get hold of any of it, I can say nothing about its medicinal virtues. It also frequently fails to cure this discase, and they have to get other aid or die. 'This completes the list of their medicines, if we omit the "charms," \&c., which their "medicine men" alone know the value of, and use very profitably at times.

'The acconchement of the femalc is somcwhat different from the

Vol. LXX.-No. 4 A 
usual mode practised by other tribes. A few hours before the time arrives, she gets up and quietly walks off alone, as if nothing extraordinary was about to occur. In this way she deceives all, even her husband, and hides herself away in some secluded nook, near a stream or hole of water. At the foot of a small tree, which she can casily grasp with both hands, she prepares her "lying-in" couch, on which she lies down as soon as labor pains come on. When the pain is on, she grasps the tree with both hands, thrown up backwards over her head, and pulls and strains with all her might, thus assisting each pain, until her accouchement is over. As soon as the child is born, the mother herself ties the navel-cord with a bit of buckskin string, severing it with a pair of scissors prepared for the occasion, after which the end is burned with a coal of fire. The child is then thrown into the water; if it rises to the surface and cries, it is taken out and cared for ; if it sinks, there it remains, and is not even awarded an Indian burial. The affair being all over, she returns to her usual duties, just the same as if nothing had happened, so matter of fact are they in such matters. During the time which I had lived here I have never heard of one of these females dying from the effects of parturition. When any of them die they are generally respectably buried; but the hut and all the effects of the deceased are burned. Even his favorite horse is sometimes killed and committed to the flames, to appease, as they say, their great grief.-San Francisco Medical Press.

\section{PROF. J. MARION SIMS.}

By the Parig Comregpondent of the London Lancet.

I HAVE some further notes to add to what I wrote in my last concerning the operative procedures of Dr. Marion Sims in respect to ccrtain injuries and disorders of women. Amputation of the cervix uteri is an opcration now regularly admitted into the surgery of women for various diseases, including cancer and hypertrophy. In such cases Dr. Marion Sims was in the habit of employing the écraseur, leaving the cut surface to heal by granulation, till about four years ago, when he hit upon a new plan, under circumstances which I will describe in his own words, from some notes which he has been good enough to furnish me at my request:-

"When the patient was fully etherized and ready for the operation, Dr. Pratt, house-surgeon to the Woman's Hospital, reported that the écraseur was broken; so I had no choice but to amputate with scissors. I intended to leave the stump to heal over in the usual way by the granulating process, which would take three or four weeks; but while examining the wound and waiting for the bleeding to cease, the idea all at once occurred to me to cover the cut surface with vaginal mucous membrane, just as we cover over the 